\title{
The Significance of Extracellular Cholesterol Crystals or a Cholesterol Granuloma in Xanthelasma
}

\author{
Frederick A. Jakobiec ${ }^{a, b}$ Lina Ma ${ }^{a, b}$ Natalie Wolkow ${ }^{a, b}$ Francis C. Sutula ${ }^{b}$ \\ Suzanne K. Freitag b, c \\ ${ }^{a}$ David G. Cogan Laboratory of Ophthalmic Pathology, Department of Ophthalmology, Massachusetts Eye and Ear \\ Infirmary, Harvard Medical School, Boston, MA, USA; 'b Massachusetts Eye and Ear Infirmary, Harvard Medical School, \\ Boston, MA, USA; ' ${ }^{O}$ Pphthalmic Plastic Surgery Service, Massachusetts Eye and Ear Infirmary, Harvard Medical \\ School, Boston, MA, USA
}

\section{Keywords}

Xanthelasma · Cholesterol crystalloids · Cholesterol granuloma $\cdot$ Hyperlipidemia $\cdot$ Arcus senilis

\begin{abstract}
Background/Aims: Xanthelasma is an unreliable indicator of systemic hyperlipidemia. A review in search of unusual histopathologic features of cellular composition that might correlate with systemic hyperlipidemia was conducted. Methods: An observational case series of 3 cases was performed. Slides were stained and analyzed with hematoxylin and eosin, Masson trichrome, and periodic acid-Schiff as well as for iron. Three lesions displayed an atypical morphologic finding and were subjected to immunohistochemical analysis for CD3, CD20, CD68, CD163, S100, and adipophilin. Results: The three lesions comprised in this study had classical xanthoma cells with densely packed fine vacuoles. The xanthoma cells were CD68, CD163, and adipophilin positive and S100 negative. In case 1, extracellular, nonpolarizing cholesterol crystalloids displayed totally negative staining for all biomarkers. In cases 2 and 3, the cholesterol granulomas were surrounded and permeated by CD68- or CD163-positive epithelioid and giant cells and by CD3-positive T lym-
\end{abstract}

\section{KARGER}

(c) 2018 S. Karger AG, Basel

E-Mail karger@karger.com

www.karger.com/oop phocytes. The 3 cases each harbored squamous cysts. Conclusion: In case 1, the uninflamed extracellular cholesterol crystalloids were associated with severely dysregulated systemic hyperlipidemia. In cases 2 and 3, the cholesterol granulomas were interpreted as a local manifestation of a cyst that might have partially ruptured and did not portend serious hyperlipidemia.

(c) 2018 S. Karger AG, Basel

\section{Introduction}

The monocyte, which arises in the bone marrow [1], enters the blood stream and ultimately migrates into the extravascular compartments where it is called a histiocyte (histo $=$ tissue). The histiocyte is capable of many morphologic modifications such as a Langerhans cell, epithelioid cell, or multinucleated giant cell. It can become either a phagocyte (macrophage) or an antigen-processing dendritic immune accessory cell. Masses of lipidized histiocytes (xanthoma cells) form a group of lesions referred to as xanthogranulomas $[2,3]$. Some of these are associated with a specific subtype of lipid disorder or systemic hyperlipidemia (e.g., eruptive or tuberous lesions [4]), 
while many are not [1]. The presence of extracellular cholesterol crystalloids in a xanthogranuloma suggests the possibility of systemic hyperlipidemia and has not been previously described [5].

Xanthelasmas of the eyelids are flat to minimally elevated xanthomatous lesions. To date the extracellular deposit of membranous or crystalloid formations of cholesterol (also called cholesterol crystals) has not been described in biopsies of xanthelasmas, the most common type of xanthomatous lesion in ophthalmology and indeed anywhere in the body. This report describes 3 atypical cases of xanthelasma: 1 with uninflamed extracellular cholesterol crystalloids that correlated with serum hyperlipidemia also encountered in some xanthomatous lesions of nonophthalmic sites $[1,5]$, and 2 with a cholesterol granuloma, more likely a reflection of local tissue events.

\section{Methods}

This study is an observational case series of 3 cases that were identified in the diagnostic files of the David G. Cogan Laboratory of Ophthalmic Pathology of the Massachusetts Eye and Ear Infirmary. The files were searched for specimens with a diagnosis of xanthelasma of the eyelids from 2004 to 2017. A total of 132 cases were discovered and reviewed out of a total of 40,000 specimens accessioned and processed in paraffin blocks. It is presumed that there were more cases of xanthelasma included with blepharoplasty specimens, many of which are not sent to the pathology laboratory for microscopic evaluation. Three cases with unusual features were identified and serve as the basis for the current study. Clinical records and photographs were collected when available. In case 3, the results of the patient's serum lipid studies could not be located. Blocks from the 3 selected cases were recut and restained with hematoxylin and eosin, Masson's trichrome, Perls' Prussian blue stain for iron, and the periodic acid-Schiff method. Immunohistochemical staining was performed for the identification of CD3-, CD20-, CD68-, and CD163-positive cells (the latter two are macrophage biomarkers) as well as $\mathrm{S} 100$ protein and adipophilin for the detection of any residual intra- or extracellular lipid after completion of tissue processing. All cases with any uncharacteristic features such as necrosis, necrobiosis, increased deposition of collagen, vasculitis, well-developed Touton cells, sarcoid granulomas, as well as large numbers of plasma cells, lymphocytes, and eosinophils were excluded.

\section{Results}

\section{Case 1}

A 65-year-old male presented for evaluation of a tight collection of yellow papules in the left medial canthus which had been present for 20 years without change and was diagnosed as a xanthelasma (Fig. 1a). He had no oth- er ocular complaints or ocular history. His past medical history was remarkable for poorly controlled hyperlipidemia, diagnosed 12 years earlier on routine blood testing. At the time of diagnosis his blood triglyceride level was $141 \mathrm{mg} / \mathrm{dL}$ (normal 40-150 mg/dL), total cholesterol was $243 \mathrm{mg} / \mathrm{dL}$ (normal <200 mg/dL), high-density lipoprotein (HDL) was $47 \mathrm{mg} / \mathrm{dL}$ (normal 35-100 mg/dL), and low-density lipoprotein (LDL) was $159 \mathrm{mg} / \mathrm{dL}$ (normal $<130 \mathrm{ng} / \mathrm{mL}$ ). The patient was unwilling to begin medical treatment, preferring to alter his diet. On subsequent visits, however, his cholesterol levels were not improved, with total cholesterol levels ranging from 235 to $304 \mathrm{mg} /$ dL and triglycerides from 185 to $553 \mathrm{mg} / \mathrm{dL}$. Simvastatin was initiated, but the patient was intermittently compliant, with total cholesterol levels continuing to range from 154 to $312 \mathrm{mg} / \mathrm{dL}$ (predominantly in the high 200s) and triglycerides from 173 to $1,930 \mathrm{mg} / \mathrm{dL}$ (predominantly in the high 300s) in subsequent years. His medical history was otherwise notable for hypertension, diabetes, and recently diagnosed chronic kidney disease.

Excision of the medial canthal lesion, which grossly measured $0.7 \times 0.4 \times 0.1 \mathrm{~cm}$, was performed in August 2017. Histopathologic examination revealed an intact epidermis deep to which were well-delineated clusters of mononuclear and multinucleated xanthoma cells with a low nuclear to cytoplasmic ratio and a small epidermal cyst (Fig. 1b, c). There were as many multinucleated as mononuclear xanthoma cells. These cells often congregated near adnexal structures and blood vessels. A polymorphic infiltrate of prominent lymphocytes, plasma cells, and eosinophils was not seen. Adjacent to the aggregates of xanthoma cells, but segregated from them, were well-circumscribed, extracellular periodic acidSchiff-negative and iron-negative locules containing feathery or leaf-like nonpolarizing crystalloid cholesterol formations (Fig. 1d). Trichrome-positive, blue collagenous septa created subdivisions of the crystalloids (Fig. 1e). An inflammatory or giant cell response was not attracted by the crystalloids. There was no significant fibrosis. Necrobiosis was not observed. There was only a paucity of mononuclear inflammatory cells in the xanthelasmatous portion of the lesion. What few mononuclear inflammatory cells there were stained for CD3 T lymphocytes to the exclusion of CD20 B lymphocytes. Immunohistochemical studies demonstrated CD163 (Fig. 1f, 2a) and adipophilin (Fig. 2b) positivity and S100 negativity in the xanthoma cells. The staining of the extracellular cholesterol crystalloids for CD163, S100, and adipophilin was negative (Fig. 1f). These negative results appeared as voids where the crystalloids were located. 

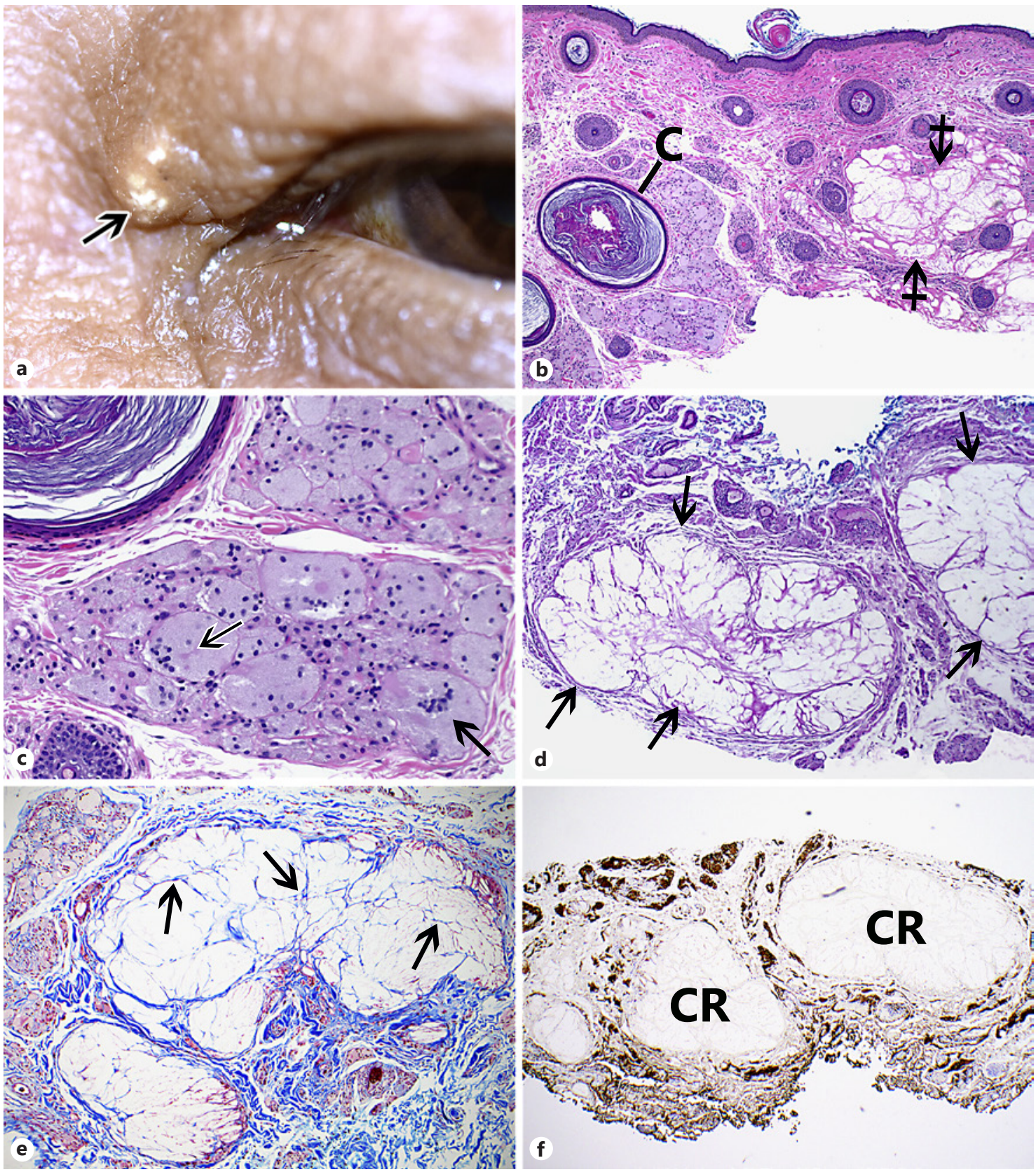

Fig. 1. Case 1. Xanthelasma with cholesterol crystals. a Unilateral left upper eyelid lesion of 20 years' duration composed of small yellowish papules. $\mathbf{b}$ A portion of skin above the orbicularis muscle displays an epidermal cyst (C) surrounded by xanthoma cells. The crossed arrows indicate a totally separate crystalloid deposit in the dermis. Hematoxylin and eosin, $\times 50$. c Next to the cyst (upper left) are clusters of xanthoma cells including multinucleated giant cells. There are scant lymphocytes. Hematoxylin and eosin, $\times 200$. d The cholesterol crystalloids are nonstaining with the periodic acidSchiff stain. Fine septa subdivide the crystalloid. The arrows indicate the perimeters of the deposits. Periodic acid-Schiff, $\times 50$. e The trichrome stain reveals that the septa are delicate strands of blue collagen. Masson trichrome stain, $\times 100$. f CD163 immunostains the xanthoma cells. The crystals (CR) appear as nonstaining voids. Immunoperoxidase stain, diaminobenzidine chromagen, hematoxylin counterstain, $\times 40$. 
Table 1. Serum lipid profiles in atypical xanthelasmas

\begin{tabular}{lll}
\hline Test performed & Case 1 (cholesterol crystals) & Case 2 (cholesterol granuloma) \\
\hline Total cholesterol (normal <200 mg/dL) & $\begin{array}{l}154-312 \mathrm{mg} / \mathrm{dL} \\
(\text { mean: } 252 \mathrm{mg} / \mathrm{dL} ; \text { median: } 262 \mathrm{mg} / \mathrm{dL})\end{array}$ & $\begin{array}{l}173-261 \mathrm{mg} / \mathrm{dL} \\
(\mathrm{mean}: 201 \mathrm{mg} / \mathrm{dL} ; \mathrm{median}: 200 \mathrm{mg} / \mathrm{dL})\end{array}$ \\
\hline LDL (normal <130 mg/mL) & $\begin{array}{l}69-186 \mathrm{mg} / \mathrm{dL} \\
(\text { mean: } 135 \mathrm{mg} / \mathrm{dL} ; \text { median: } 149 \mathrm{mg} / \mathrm{dL})\end{array}$ & $\begin{array}{l}82-125 \mathrm{mg} / \mathrm{dL} \\
(\mathrm{mean}: 105 \mathrm{mg} / \mathrm{dL} ; \mathrm{median}: 110 \mathrm{mg} / \mathrm{dL})\end{array}$ \\
\hline HDL (normal 35-100 mg/dL) & $\begin{array}{l}37-58 \mathrm{mg} / \mathrm{dL} \\
(\text { mean: } 47 \mathrm{mg} / \mathrm{dL} ; \text { median: } 48 \mathrm{mg} / \mathrm{dL})\end{array}$ & $\begin{array}{l}35-56 \mathrm{mg} / \mathrm{dL} \\
(\mathrm{mean}: 51 \mathrm{mg} / \mathrm{dL} ; \mathrm{median}: 53)\end{array}$ \\
\hline Triglycerides $($ normal 50-140 mg/dL) & $\begin{array}{l}141-1,930 \mathrm{mg} / \mathrm{dL} \\
(\text { mean: } 416 \mathrm{mg} / \mathrm{dL} ; \text { median: } 335 \mathrm{mg} / \mathrm{dL})\end{array}$ & $\begin{array}{l}112-322 \mathrm{mg} / \mathrm{dL} \\
(\mathrm{mean}: 217 \mathrm{mg} / \mathrm{dL} ; \mathrm{median}: 225 \mathrm{mg} / \mathrm{dL})\end{array}$ \\
\hline
\end{tabular}

Serum lipid profile not available in case 3. HDL, high-density lipoprotein; LDL, low-density lipoprotein.

\section{Case 2}

A 67-year-old woman presented for evaluation of bilateral medial upper eyelid lesions which had slowly developed over the course of 2 years (Fig. 2c). She had an ocular history of eyelid papillomas which had been excised several years earlier, cataract surgery in both eyes, and dry age-related macular degeneration. Her medical history was notable for endometrial cancer, for which she had undergone hysterectomy 21 years earlier, hypertension, and morbid obesity (body mass index 55.8). She had struggled with obesity since her teenage years, finally undergoing a gastric adjustable laparoscopic band placement 8 years prior to presentation, without significant weight loss. Her serum triglycerides had been chronically elevated for 15 years, ranging from 112 to $322 \mathrm{mg} / \mathrm{dL}$ (mostly in the low 200s) (normal $40-150 \mathrm{mg} / \mathrm{dL}$ ), while her HDL and LDL levels had been normal. Her most recent lipid panel demonstrated an HDL of $53 \mathrm{mg} / \mathrm{dL}$ (normal 35-100 mg/dL), an LDL of $112 \mathrm{mg} / \mathrm{dL}$ (normal $<130 \mathrm{ng} / \mathrm{mL}$ ), a total cholesterol of $209 \mathrm{mg} / \mathrm{dL}$ (normal $<200 \mathrm{mg} / \mathrm{dL}$ ), and triglycerides of $219 \mathrm{mg} / \mathrm{dL}$ (normal $40-150 \mathrm{mg} / \mathrm{dL}$ ). She was on two antihypertensives, atenolol, indapamide, and multivitamins, but had never taken cholesterol- or lipid-lowering agents. Physical examination in the Ophthalmic Plastic Surgery Clinic revealed medial bilateral upper eyelid xanthelasmas as well as a left upper eyelid inclusion cyst. Bilateral lower eyelid fat prolapse was also noted and had been present for many years according to the patient. No arcus senilis was observed. Fundoscopic examination was notable for bilateral macular drusen.

The xanthelasmas of both upper eyelids were excised. The gross specimens measured $1.6 \times 0.5 \times 0.4 \mathrm{~cm}$ and $1.8 \times 0.5 \times 0.4 \mathrm{~cm}$. Histopathologic examination revealed xanthoma cells occupying the full thickness of the dermis down to the orbicularis muscle (Fig. 2d). Two epidermoid cysts were found among the xanthoma cells, and there were more dispersed lymphocytes than observed in cases 1 and 3. Most notable was an extensive nonpolarizing cholesterol granuloma (Fig. 2e) which centrally appeared to melt into amorphous eosinophilic material. CD68 and CD163 immunostained the xanthoma cells as well as the mononucleated epithelioid cells and giant cells. These surrounded the cholesterol clefts and also penetrated into the granulomas (Fig. 3a). No inflammatory polymorphous cells were observed. Adipophilin was positive in the granulomatous inflammatory cells, but only at their peripheries (Fig. 3b). S100 was uniformly negative. CD3positive T lymphocytes far outnumbered CD20 B lymphocytes and together were more numerous than in cases 1 and 3 . The iron stain was negative.

\section{Case 3}

A 74-year-old man was evaluated in April 2005 for yellowish lesions of the medial region of both lower eyelids. They had allegedly been present since his fifties and had reached a stable state. There was no known history of coronary artery disease or elevated blood lipid levels requiring a cholesterol-lowering drug regimen. The results of serum lipid studies, however, were not found because the medical records were not completely available due to storage at an out-of-hospital facility where most could not be located. Also a changeover in the medical record computer system of the Massachusetts General Hospital/ Massachusetts Eye and Ear Infirmary had not captured all of the data contained in the hand-written forms from the earlier paper records. 

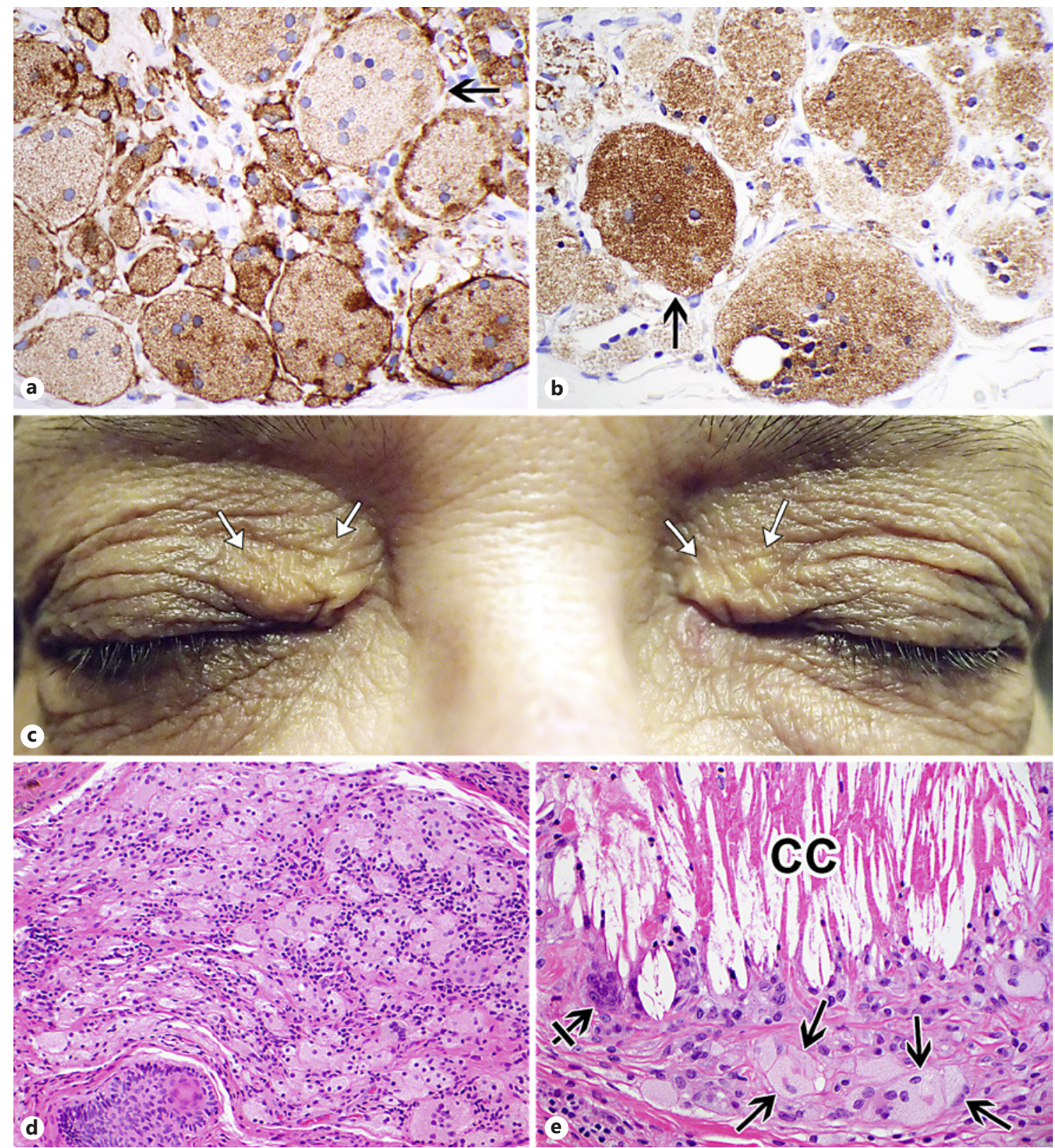

Fig. 2. Additional immunohistochemical staining in case 1 and staining in case 2. a CD163 strongly stains the mononucleated xanthoma cells and more weakly the multinucleated cells (arrow) which preponderate this field. The lipid in the giant cells probably diluted the cytoplasmic antigen represented by the biomarker. Immunoperoxidase stain, $\times 600$. $\mathbf{b}$ Adipophilin stains the xanthoma cells, one especially intensely (arrow). Immunoperoxidase stain, $\times 600$. c Case 2 . Xanthelasma with cholesterol granuloma. Bilateral elevated medial upper eyelid lesions of 2 years' duration (arrows). d The xanthoma cells display more dispersed lymphocytes among them than those in cases 1 and 3. Hematoxylin and eosin stain, $\times 200$. e Granuloma with perpendicular elongated cholesterol clefts (CC) surrounded by mononucleated epithelioid cells and giant cells (crossed arrow). The arrows toward the bottom highlight entrapped tumor xanthoma cells. Hematoxylin and eosin stain, $\times 400$. 

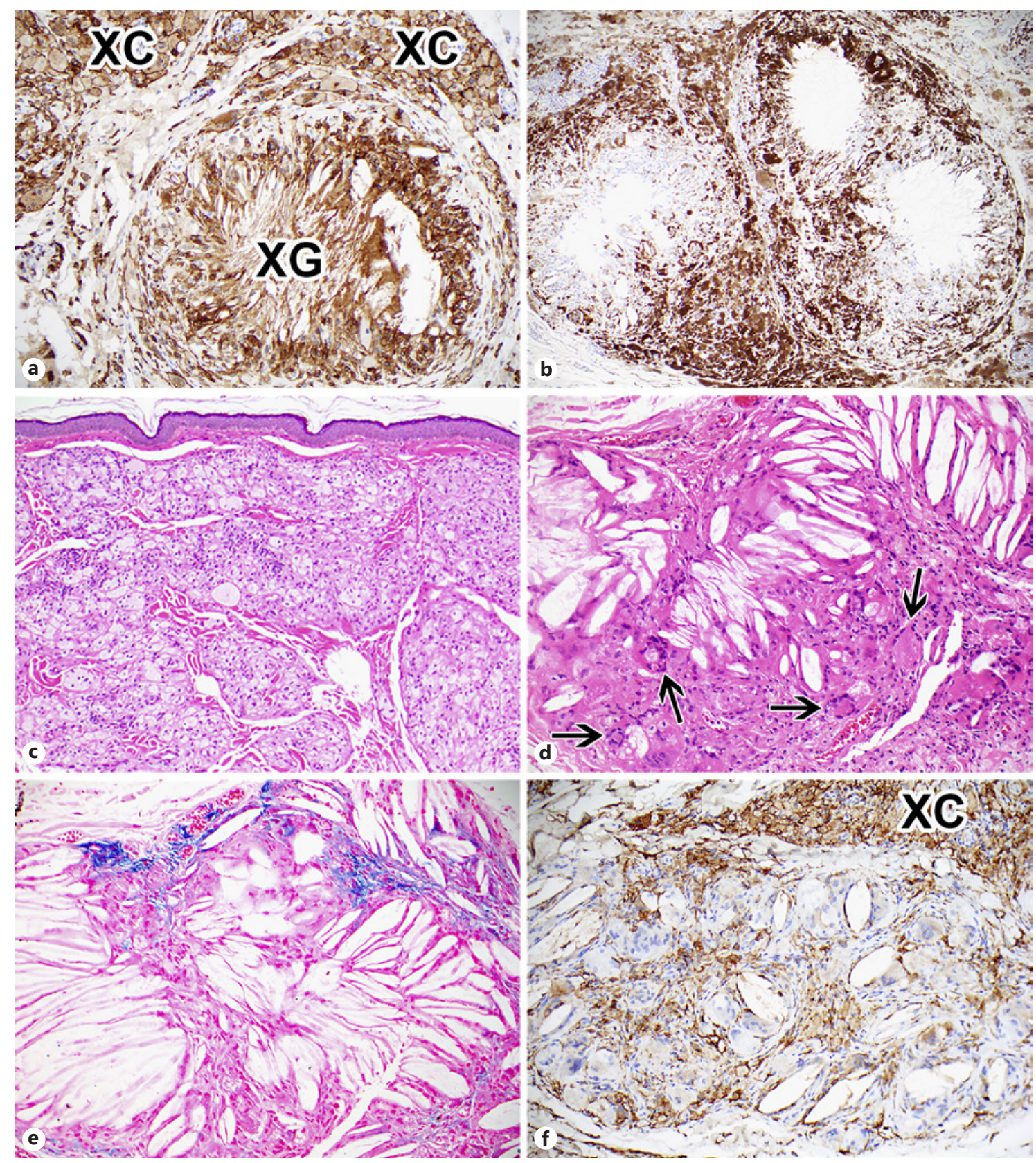

Fig. 3. Additional immunohistochemical staining in case 2 and results in case 3. a CD163 stains the periphery and the center of the cholesterol granuloma (XG). Tumor xanthoma cells (XC) are present outside of the granuloma. Immunoperoxidase stain, $\times 200$. b Adipophilin stains the outer rims of three confluent granulomas but not their centers. Immunoperoxidase stain, $\times 200$. c Case 3 . Typical rarefied xanthoma cells occupy the dermis and spare the epidermis. Hematoxylin and eosin, $\times 100$. d A cholesterol granu- loma with a mass of mononucleated epithelioid cells and admixed giant cells (arrows) in the bottom half of the field. Hematoxylin and eosin, $\times 200$. e The Prussian blue stain for iron indicative of blood breakdown products stains several regions of the granuloma. Prussian blue stain, $\times 200$. $f$ CD163 is present in xanthoma cells (XC) and also labels macrophages that penetrate in between the cholesterol clefts. Immunoperoxidase stain, $\times 200$. 
The excised bilateral eyelid specimens were tan-gray skin ellipses. The one from the right lower eyelid grossly measured $1.2 \times 0.4 \times 0.3 \mathrm{~cm}$, while the one from the left lower eyelid measured $0.7 \times 0.5 \times 0.3 \mathrm{~cm}$. Histopathologically the lesions were composed of the same type of xanthoma cells as described in cases 1 and 2, except for fewer multinucleated giant xanthoma cells (Fig. 3c). A nonruptured epidermoid cyst was observed. Neither hemorrhage nor necrobiosis was evident. The atypical finding was a prominent cholesterol granuloma found in the midst of the xanthelasmatous lesion. It exhibited nonpolarizing, elongated cholesterol clefts enclosing extremely delicate, thin eosinophilic strands (Fig. 3d). A granulomatous response was observed around the cholesterol spaces best described as slits or clefts. Multiple foci of iron deposition and adipophilin positivity in some histiocytes were detected in the granuloma (Fig. 3e). Nearby there were two cysts, one vellous and the other epithelioid. Immunohistochemically the xanthoma cells were CD163- and adipophilin-positive; the granuloma was heavily permeated by CD163-positive mononucleated epithelioid cells and multinucleated giant cells as well as by CD3-positive T lymphocytes (Fig. 3f).

For ease of comparison, Table 1 summarizes the results of serum lipid studies for cases 1 and 2 .

\section{Discussion}

The multifocal development of xanthomas is sometimes referred to as xanthogranulomatosis, whereas a unifocal, localized lesion is simply termed a xanthogranuloma. The limited form of xanthogranuloma known to most ophthalmologists is exemplified by juvenile xanthogranuloma [6], which, in addition to involvement of the iris with the production of a hyphema, can exceptionally and limitedly involve internal organs [7-9]. Xanthogranulomas must be distinguished from lipogranulomas. The latter exhibit locules of extracellular lipid surrounded by epithelioid histiocytes and other inflammatory cells [2, 10]. The chalazion is the prime example of a lipogranuloma in ophthalmology - a blockage in a draining duct of a Meibomian gland secretory unit with extrusion of the lipid synthesized by the Meibomian acinar cells into the tarsus, surrounding orbicularis muscle, and dermis. Extracellular lipid is irritating and attracts a granulomatous response. The histiocytes in the chalazion are for the most part nonlipidized (nonxanthomatous). Other causes of lipogranulomas are trauma to the orbital fat, injections of foreign lipidic material or cosmetic fillers, infection, an exuberant idiopathic inflammation predominantly involving the orbital fat, and vasculitis [10].

Xanthelasma (Greek: xanthos = yellow, elasma = beat en metal plate or plaque) usually appears in women aged $30-50$ years. The youngest individuals can be in their first two decades of life and have family histories of xanthelasma with or without hyperlipidemia [11, 12]. Women are more often affected (over 80\%) than men [13]. Among the 132 lesions observed at the Massachusetts Eye and Ear Infirmary from 2004 to 2017, women had more xanthelasma excisions than men ( 76 vs. $24 \%$ ), probably due to their heightened cosmetic concerns. The lesions typically originate in the medial upper and lower eyelids and canthal region. It should be remembered that eyelid blinking commences laterally and spreads medially in a wave-like fashion, thereby "milking" the lipid-rich interstitial fluids toward the midline. In this regard there is a reported case of unilateral paralysis of the eyelids with a xanthelasma developing only on the nonparalyzed side [14].

The earliest lesions may be small confluent papules in the medial canthal region, as in the current case; their main cytoplasmic constituent is cholesteryl ester that derives from the blood [15]. The lesion ultimately becomes a yellow creamy or light-brown plaque with minimal elevation, clear-cut margins, and a velvety, soft texture due to the absence of conspicuous fibrosis $[1,3]$. Sometimes the lesion has a creviced surface created by the conglomeration of multiple papules. Extremely rare lesions are tumoral, elevated masses [16], and patients with autosomal dominant familial hypercholesterolemia may have multiple plaques [4]. Nilotinib, an antileukemic drug, can induce xanthelasma formation [17]. Corneal arcus senilis is associated with xanthelasmas in 20\% of cases [13].

A recent study of 49 cases of xanthelasmas established that $86 \%$ presented with a plaque morphology and $14 \%$ as papules [13]. Ten of 49 cases also had an arcus senilis. The average lipid values were cholesterol $211 \mathrm{mg} / \mathrm{dL}$, triglycerides $123 \mathrm{mg} / \mathrm{dL}$, LDL $143 \mathrm{mg} / \mathrm{dL}$, and very-lowdensity lipoprotein $31 \mathrm{mg} / \mathrm{dL}$. In the current case 1 , uninflamed extracellular cholesterol crystalloid deposits were found - an unusual finding indicative of severe lipid dysregulation. These crystalloid formations appeared as empty noninflamed spaces between trichrome-positive membranous collagenous strands that could be likened overall to an etiolated leaf with visible veins. Alcohol exposure in the preparation of microscopic slides had dissolved out the cholesterol content which, however, in cryosections in another study [5] has been shown to have a rod-like configuration. These rods did not stain with Sudan III dye, while the cytoplasm of the xanthoma cells 
was positively stained [5]. In contrast, inflammogenic cholesterol clefts have been detected in necrobiotic foci and nonocular xanthomatous and other tumors $[1,3,18$, 19]. Cholesterol crystalloids are more rarely seen than cholesterol granulomas, even in xanthomas.

There has long been debate over whether xanthelasma is a cutaneous reflection of underlying atherosclerosis and a deranged and defective lipid metabolism causing high levels of serum cholesterol and lipoproteins [20]. The current study has demonstrated that cholesterol crystalloids correlated with a more deranged lipid status than a cholesterol granuloma (Table 1). In an earlier review, it was determined that half of the patients with xanthelasma had normal serum lipid levels and half manifested lipid dysregulation; there were no distinguishing microscopic findings between the two groups [20]. In another series, $7 \%$ of patients with xanthelasma had coronary artery disease [21]. Xanthelasma has been studied as a marker of premature atherosclerosis by discovering ultrasonographic thickening of the carotid intima [22]. Defects in lipoproteins, apolipoproteins (proteins that bind lipids and transport them through the lymphatic and circulatory systems), apoenzymes, and vascular permeability in the face of normal serum lipid levels are other possible contributing mechanisms for the genesis of xanthelasma [23-25]. In a recent study [26], immunohistochemical staining of paraffin sections of xanthelasmas revealed a wide range of upregulated inflammatory cofactors paralleling those found in the early stages of cardiac atherosclerotic plaque formation. Contrariwise, the use of statins may induce resolution of xanthelasmas [27].

Histopathologically the present lesions were composed of lipidized histiocytes fully occupying the dermis (xanthoma cells) and often reaching the level of the orbicularis muscle [1-3]. The epidermis was intact. The lipid vacuoles were extremely fine and densely crowded, conferring a clear-cell appearance. Scattered multinucleated giant cells possessed randomly distributed, small, round, dark nuclei. Classical Touton giant cells with central eosinophilic cytoplasm separated from an outer rim of frothy-vacuolated cytoplasm by an annulus of nuclei are not typical of xanthelasma, although some giant cells can closely simulate Touton cells. The xanthoma cells had a tendency to be oriented in a perivascular or periadnexal pattern. A heavy secondary inflammatory cell infiltrate was not featured among the xanthoma cells except in case 2 ; there were no signs of necrobiotic changes in the collagen [1]. The naked extracellular cholesterol crystalloids observed in the present case 1 had elicited no inflammatory reaction and correlated with systemic dysregulation of serum lipids. A possible mechanism for the formation of the extracellular crystalloids was the collection of such high levels of interstitial cholesterol that the already bloated macrophages were unable to imbibe any more of the molecules.

As a counterpoint, the current cases 2 and 3 displayed an inflammogenic cholesterol granuloma with slit-like spaces or clefts engulfed by mononucleated epithelioid cells and multinucleated giant cells and accompanied by CD3-positive lymphocytes but not CD20-positive B lymphocytes. This kind of reaction can be seen in necrobiotic foci, in the wake of a local hemorrhage, foci with blood breakdown products, in relation to a disrupted keratin- or mucin-bearing cyst [28-31], or in response to tissue necrosis or foreign or implanted lipidic material (oldfashioned paraffin injections causing granulomatous paraffinomas [10]). The detection of iron in case 3 partially supports a prior local event generating blood breakdown products. The granulomatous inflammation represents either a foreign body type of response or a delayed hypersensitivity reaction to altered or denatured membraneassociated lipids or lipoproteins. In essence, a cholesterol granuloma is a morphologic variant of a lipogranuloma with a striking radiating or elongated arrangement of once lipidized slits or clefts.

Both epidermoid cysts and a delicate and deformable vellus-hair-type cyst $[29,30]$ were observed in proximity to all the patients' classical xanthelasmas and cholesterol granulomas; the latter interdigitated with some of the lesion's xanthoma cells. An eyelid cholesterol granuloma may follow the rupture of a cyst [29]. In our specimens, however, no remnants of a cyst's epithelial lining were discovered, perhaps due to total destruction by the granulomatous response. In other nonophthalmic sites and tissues where cholesterol granulomas develop, there has been no relationship established with respect to abnormalities in serum lipids [32-36]. Examples include a leaking craniopharyngioma or Rathke's pouch cyst, skin cysts, inflammation of the petrous bone apex, and involvement of the hypophysis, mediastinum, kidney, breast, parotid, testis, liver, spleen, and peritoneum [32, $33,35]$. On the other hand, uninflamed cholesterol crystalloids are highly suggestive of an accompanying serum hyperlipidemia (Table 1) and should prompt a thorough serum lipid profile and apolipoprotein analysis. Despite the lack of serum studies from the missing portions of the third patient's records, it can nonetheless be inferred that the cholesterol granuloma was an entirely separate, local lesion. 
Two xanthomatous conditions must finally be mentioned as harbingers of potentially lurking lymphoproliferative diseases. The first is diffuse plane xanthoma, which is a decidedly less important condition for ophthalmologists because this lesion generally does not affect the periocular skin $[1,5]$. More likely to be encountered is necrobiotic xanthogranuloma [28], which may initially have an associated paraproteinemia that can evolve into a full-fledged lymphoma several years later. Indurated plaques usually develop; these may appear yellow with telangiectasias, atrophy, surface ulceration, and fistulas, findings not evidenced by xanthelasma. In a series of 22 necrobiotic lesions, 21 were found in the periocular region [28]. The most significant finding is necrobiosis of the collagen, signifying its loss of tinctorial properties due to denaturation. The altered collagen can have cholesterol clefts or slits and is sequestered by a palisading granuloma surrounded by xanthoma cells and Touton giant cells. The necrotic collagen may be shed by means of transepidermal (or transconjunctival) elimination, which can also be seen with masses of keratin [37].

There is a report of bilateral xanthelasmas and an orbital xanthoma occurring together [38]. The orbital xanthoma, however, was actually a necrobiotic xanthogranuloma and was probably unrelated to the xanthelasma, which does not harbor foci of necrobiosis and is not a forerunner of lymphoma. Somewhat more convincing is a report of bilateral xanthelasmas occurring in a 7-yearold child with a family history of hypercholesterolemia who developed leukemia that was associated with multi- ple truncal juvenile xanthogranulomas [39]. This raises a residual doubt as to whether the eyelid lesions were actually juvenile xanthogranulomas, which have a reputation for an association with neurofibromatosis and leukemia along with other neoplasms [3]. A report of bilateral, multifocal, bulky tumors [40] raises the question of whether another histiocytic disease may have been responsible, such as Rosai-Dorfman sinus histiocytosis, ErdheimChester disease, reticulohistiocytomas, or adult-onset asthma with orbital xanthogranulomas [41-44].

\section{Acknowledgment}

Natalie Wolkow is supported by a Heed Ophthalmic Fellowship.

\section{Statement of Ethics}

The study was submitted for review by the Institutional Review Board of the Massachusetts Eye and Ear Infirmary and was granted a waiver due to the small number of cases and the retrospective nature of the study. The study was conducted in accordance with the tenets of the Helsinki Declaration and in compliance with the rules and regulations of the Health Insurance Portability and Accountability Act.

\section{Disclosure Statement}

The authors declare no conflicts of interest.

\section{References}

1 Burgdorf WHC, Zelger B: The histiocytoses; in Lever WF, Elder DE (eds): Lever's Histopathology of the Skin. Philadelphia, Wolters Kluwer/Lippincott Williams \& Wilkins, 2009, pp 667-688.

2 Font RL: Eyelids and lacrimal drainage system; in Spencer WH (ed): Ophthalmic Pathology: An Atlas and Textbook. Philadelphia, W.B. Saunders Co., 1996, vol 4, pp 2334-2339, 2355.

3 Weedon D: Cutaneous infiltrates - non-lymphoid; in Weedon D (ed): Weedon's Skin Pathology. Edinburgh, Churchill Livingstone/ Elsevier, 2010, pp 937-970.

-4 Pietroleonardo L, Ruzicka T: Skin manifestations in familial heterozygous hypercholesterolemia. Acta Dermatovenerol Alp Pannonica Adriat 2009;18:183-187.

5 Onishi R, Ohno S, Wakasa T, Horiguchi Y: Cutaneous cholesterol deposits associated with normolipidemic disseminated plane xanthoma: alabaster granule-like dots on the cheek. Int J Dermatol 2013;52:1456-1458.

-6 Zimmerman LE: Ocular lesions of juvenile xanthogranuloma. Nevoxanthoendothelioma. Am J Ophthalmol 1965;60:1011-1035.

-7 Ferguson SD, Waguespack SG, Langford LA, Ater JL, McCutcheon IE: Fatal juvenile xanthogranuloma presenting as a sellar lesion: case report and literature review. Childs Nerv Syst 2015;31:777-784.

8 Freyer DR, Kennedy R, Bostrom BC, Kohut G, Dehner LP: Juvenile xanthogranuloma: forms of systemic disease and their clinical implications. J Pediatr 1996;129:227-237.

-9 Janssen D, Harms D: Juvenile xanthogranuloma in childhood and adolescence: a clinicopathologic study of 129 patients from the Kiel Pediatric Tumor Registry. Am J Surg Pathol 2005;29:21-28.
10 Jakobiec FA, Rai R, Rashid A, Sutula FC: Bilateral eyelid pseudoptosis from lipogranulomas of the preaponeurotic fat pads. Ophthal Plast Reconstr Surg 2015;31:e125-e131.

11 Depot MJ, Jakobiec FA, Dodick JM, Iwamoto T: Bilateral and extensive xanthelasma palpebrarum in a young man. Ophthalmology 1984;91:522-527.

12 Youn SJ, Park HS, Kim WS, Lee ES, Yang JM: Bilateral xanthelasma palpebrarum on both eyelids in a 9-year-old boy. Pediatr Dermatol 2006;23:95-97.

13 Nair PA, Patel CR, Ganjiwale JD, Diwan NG, Jivani NB: Xanthelasma palpebrarum with arcus cornea: a clinical and biochemical study. Indian J Dermatol 2016;61:295-300.

14 Cho YH, Lee HJ, Kim DS, Lee MG: Unilateral xanthelasma sparing a paralysed eyelid. J Eur Acad Dermatol Venereol 2007;21:105106. 
15 Bergman R, Kasif Y, Aviram M, Maor I, Ullman Y, Gdal-On M, Friedman-Birnbaum R: Normolipidemic xanthelasma palpebrarum: lipid composition, cholesterol metabolism in monocyte-derived macrophages, and plasma lipid peroxidation. Acta Derm Venereol 1996; 76:107-110.

16 Tosti A, Varotti C, Tosti G, Giovannini A: Bilateral extensive xanthelasma palpebrarum. Cutis 1988;41:113-114.

-17 Sayin I, Ayli M, Oguz AK, Seval GC: Xanthelasma palpebrarum: a new side effect of nilotinib.BMJCaseRep2016;2016:bcr2015213511.

-18 Deguchi M, Aiba S: Cholesterotic fibrous histiocytoma in a patient with metabolic syndrome. Case Rep Dermatol 2017;9:136-140.

$>19$ Huang GS, Huang CW, Lee CH, Taylor JA, Lin CG, Chen CY: Xanthoma of the sacrum. Skeletal Radiol 2004;33:674-678.

20 Bergman R: The pathogenesis and clinical significance of xanthelasma palpebrarum. J Am Acad Dermatol 1994;30:236-242.

$>21$ Dey A, Aggarwal R, Dwivedi S: Cardiovascular profile of xanthelasma palpebrarum. Biomed Res Int 2013;2013:932863.

-22 Pandhi D, Gupta P, Singal A, Tondon A, Sharma S, Madhu SV: Xanthelasma palpebrarum: a marker of premature atherosclerosis (risk of atherosclerosis in xanthelasma). Postgrad Med J 2012;88:198-204.

23 Ozdol S, Sahin S, Tokgozoglu L: Xanthelasma palpebrarum and its relation to atherosclerotic risk factors and lipoprotein (a). Int J Dermatol 2008;47:785-789.

-24 Tursen U, Eskandari G, Kaya TI, Tamer L, Ikizoglu G, Atik U: Apolipoprotein E polymorphism and lipoprotein compositions in normolipidaemic xanthelasma patients. J Eur Acad Dermatol Venereol 2006;20:260-263.

25 Wilkinson SM, Atkinson A, Neary RH, Smith AG: Normolipaemic plane xanthomas: an association with increased vascular permeability and serum lipoprotein(a) concentration. Clin Exp Dermatol 1992;17:211-213.
26 Govorkova MS, Milman T, Ying GS, Pan W, Silkiss RZ: Inflammatory mediators in xanthelasma palpebrarum: histopathologic and immunohistochemical study. Ophthal Plast Reconstr Surg 2017, Epub ahead of print.

27 Shields CL, Mashayekhi A, Shields JA, Racciato P: Disappearance of eyelid xanthelasma following oral simvastatin (Zocor). Br J Ophthalmol 2005;89:639-640.

28 Finan MC, Winkelmann RK: Necrobiotic xanthogranuloma with paraproteinemia. A review of 22 cases. Medicine (Baltimore) 1986;65:376-388.

29 Jakobiec FA, Stagner AM, Freitag SK, Yoon MK: Unusual eyelid dermal keratinous cysts of pilosebaceous origin. Ophthal Plast Reconstr Surg 2016;32:93-97.

30 Utsunomiya N, Oyama N, Chino T, Tokuriki A, Sakai Y, Imamura Y, Hasegawa M: Multiple subcutaneous cholesterol granulomas arising in eruptive vellus hair cysts: a case report and published work review of 11 cases. J Dermatol 2017;44:481-482.

31 Zhang M, Tie HT, Wang CL, Wu QC: Pulmonary interstitial cholesterol crystals associated with diffuse lung cysts in adult: a case report and literature review. J Cardiothorac Surg 2016;11:11.

32 Drury NE, Smith DN, Phillips LM, Trotter SE, Kalkat MS: Cholesterol granuloma of the anterior mediastinum. Thorax 2017;72:671672.

33 Hernandez-Estrada RA, Kshettry VR, Vogel AN, Curtis MT, Evans JJ: Cholesterol granulomas presenting as sellar masses: a similar, but clinically distinct entity from craniopharyngioma and Rathke's cleft cyst. Pituitary 2017;20:325-332

34 Kim YS, Ju HJ, Park CJ, Lee KH: A case of cholesterol granuloma presenting as a cutaneous nodule. Ann Dermatol 2017;29:383-384.

35 Kleinschmidt-DeMasters BK, Lillehei KO, Hankinson TC: Review of xanthomatous lesions of the sella. Brain Pathol 2017;27:377395.
36 Hughes JD, Jacob JT, Garrity JA, Salomao DR, Link MJ: Orbitofrontal cholesterol granuloma: four case reports and a systematic review of the English literature. World Neurosurg 2016;87:355-361.

37 Gologorsky D, Jakobiec FA, Freitag SK: Transconjunctival elimination of keratin from an intratarsal meibomian cyst. Ophthal Plast Reconstr Surg 2013;29:e88-e91.

38 Rubinstein TJ, Mehta MP, Schoenfield L, Perry JD: Orbital xanthogranuloma in an adult patient with xanthelasma palpebrarum and hypercholesterolemia. Ophthal Plast Reconstr Surg 2014;30:e6-e8.

39 Le Bidre E, Delage M, Lejars O, Machet MC, Lorette G, Maruani A: Xanthelasma and juvenile xanthogranuloma in a 7-year-old boy (in French). Ann Dermatol Venereol 2009;136: 723-726.

40 Wang P, Luo Q, Tang L: Bilateral extensive nodular xanthelasma palpebrarum: an infrequent case report. Int Ophthalmol 2017, Epub ahead of print.

41 Baykal C, Polat Ekinci A, Yazganoglu KD, Buyukbabani N: The clinical spectrum of xanthomatous lesions of the eyelids. Int J Dermatol 2017;56:981-992.

42 Jakobiec FA, Kirzhner M, Tollett MM, Mancini R, Hogan RN: Solitary epithelioid histiocytoma (reticulohistiocytoma) of the eyelid. Arch Ophthalmol 2011;129:1502-1504.

43 Jakobiec FA, Mills MD, Hidayat AA, Dallow RL, Townsend DJ, Brinker EA, Charles NC: Periocular xanthogranulomas associated with severe adult-onset asthma. Trans Am Ophthalmol Soc 1993;91:99-125; discussion 125129.

44 Sivak-Callcott JA, Rootman J, Rasmussen SL, Nugent RA, White VA, Paridaens D, Currie Z, Rose G, Clark B, McNab AA, Buffam FV, Neigel JM, Kazim M: Adult xanthogranulomatous disease of the orbit and ocular adnexa: new immunohistochemical findings and clinical review. Br J Ophthalmol 2006;90:602608 . 